\title{
Comparative efficacy of hospital disinfectants against nosocomial infection pathogens
}

\author{
Fahim Amini Tapouk ${ }^{1}$, Ramin Nabizadeh ${ }^{2,3^{*}}$, Nezam Mirzaei ${ }^{4}$, Nima Hosseini Jazani ${ }^{5}$, Mahmood Yousefi ${ }^{6}$ and \\ Mohamad Amin Valizade Hasanloei ${ }^{7}$
}

\begin{abstract}
Background: Due to the increasing rate of hospital-acquired infections, it is essential to select appropriate disinfectant agents. In this study, the efficacy of hospital disinfectants against nosocomial infection pathogens was compared.

Methods: High level disinfectants (Steranios 2\%, Deconex HLDPA, and Microzed Quatenol) were tested for their antibacterial effects by determining their minimum inhibitory (MIC) and minimum bactericidal concentrations (MBC) against Enterococcus faecalis ATCC 29212 and Burkholderia cepacia ATCC 10673.

Results: E. faecalis, as gram-positive bacterium, was more susceptible to high level disinfectants compared to gramnegative B.cepacia. The MIC = MBC values of $2 \%$ Steranios, Deconex HLDPA and Microzed Quatenol against $E$. faecalis and B.cepacia were $0.31,9.77,2.2 \mathrm{mg} / \mathrm{L}$ and $9.8,78.13,70.31 \mathrm{mg} / \mathrm{L}$, respectively.

Conclusions: According to the findings of this study, the most effective disinfectants against both $E$. faecalis and B.cepacia were Steranios 2\%, Microzed Quatenol, and Deconex HLDPA in order. Considering the importance of these bacterial strains in healthcare-associated infections, the use of these effective disinfectants is recommended in the hospitals.
\end{abstract}

Keywords: Health care associated infections, nosocomial infection pathogens, High level disinfectants, Minimum inhibitory concentration (MIC), Enterococcus faecalis ATCC 29212, Burkholderia cepacia ATCC 10673

\section{Introduction}

Healthcare-associated infections with approximately 7.1 million annual cases and 99,000 annual deaths in the United States have been recognized as a group of important causes of morbidity and mortality in admitted patients [1]. The patient's microbiota is believed to be the major source of infections that are transmitted from the medical staff and the hospital environment.

\footnotetext{
* Correspondence: rnabizadeh@tums.ac.ir; rnabizadeh@gmail.com 2Department of Environmental Health Engineering, School of Public Health Tehran University of Medical Sciences, Tehran, Iran

${ }^{3}$ Center for Air Pollution Research (CAPR), Institute for Environmental Research (IER), Tehran University of Medical Sciences, Tehran, Iran Full list of author information is available at the end of the article
}

Approximately $20-40 \%$ of these infections are transmitted via hands $[2,3]$. Hospital-acquired infections are a major concern in health care centers, which may also increase the length of hospitalization, costs and mortality rate in patients [4]. Contamination of the hospital environment plays a significant role in the transmission of several pathogens such as Methicillin-resistant Staphylococcus aureus (MRSA) and Vancomycin-resistant Enterococcus (VRE) [4, 5]. Another bacterial species that has been important in recent years as a multi-drug resistance agent of hospital infections is Burkholderia cepacia, which was first described in patients with systemic fibrosis in the late 1970s. Burkholderia cepacia

(C) The Author(s). 2020 Open Access This article is licensed under a Creative Commons Attribution 4.0 International License, which permits use, sharing, adaptation, distribution and reproduction in any medium or format, as long as you give appropriate credit to the original author(s) and the source, provide a link to the Creative Commons licence, and indicate if changes were made. The images or other third party material in this article are included in the article's Creative Commons licence, unless indicated otherwise in a credit line to the material. If material is not included in the article's Creative Commons licence and your intended use is not permitted by statutory regulation or exceeds the permitted use, you will need to obtain permission directly from the copyright holder. To view a copy of this licence, visit http://creativecommons.org/licenses/by/4.0/. The Creative Commons Public Domain Dedication waiver (http://creativecommons.org/publicdomain/zero/1.0/) applies to the data made available in this article, unless otherwise stated in a credit line to the data. 
isolates are usually resistant to various classes of antibiotics and disinfectants [6]. Enterococci have been long recognized as important human pathogens and Enterococcus faecalis is one of the most common and lifethreatening causes of nosocomial infections $[7,8]$. In the healthcare setting Enterococcus faecalis was known as an important cause of hospital-acquired bacteremia and mortality among the elderly and patients with major disorder conditions [9].

To prevent infections, it is important to remove bacterial biofilms from contaminated surfaces equipment and the medical environment [10]. Contaminated hospital surfaces can transmit the pathogens to the patients, so cleaning and disinfecting surfaces will break this chain [1]. Decontamination methods such as sterilization (physical or chemical) and disinfection processes are key principles of successful programs in the control of nosocomial infections [6]. Persistence of hospital infections may be in part due to the inappropriate and inadequate use of decontamination methods [11]. In hospitals, medical instruments are classified into three categories of critical, semi-critical, and non-critical based on the risk of infection transmission and contact with the patient's body. Critical items enter sterile tissues so the use of these devices increases the risk of infection if they are not properly disinfected; therefore, in these cases applying liquid chemical disinfectants is essential after reuse $[7,12]$. The main purpose of using disinfectants in hospitals is to reduce the risk of sporadic and epidemic infections. To achieve this goal, different methods and various disinfectants are recommended $[13,14]$. Furthermore, due to the changing patterns of resistance in nosocomial pathogens, daily revision of the efficacy of disinfectants and chemical sterilizers against multi-drug resistant pathogens seems necessary [15].

However, due to the accessibility of various and different brands of disinfectant products, selection of the right one has become a challenge for environmental health experts and infection control supervisors in the health-care settings. The choice of disinfectants according to the manufacturer's instructions is not only unreliable but also causes irreversible damages to instruments and increases the rate of outbreaks related to the disinfectant-resistant pathogens in hospitals in some cases. As an environmental health expert working in a hospital, i have an unpleasant experience in this field because one of our endoscopic devices was seriously damaged after a few months of using the peroxyacetic acid (PAA) solution.

Therefore, it is necessary to investigate the sensitivity of bacterial pathogens to currently used disinfectants by different methods such as determining the minimum inhibitory concentration (MIC) and minimum bactericidal concentration (MBC). The aim of the present study was to determine the efficacy of high level disinfectants against two multidrug resistant bacterial pathogens, $E$. faecalis (ATCC 29212) and B. cepacia (ATCC 10673), by determining the MIC and MBC of each disinfectant and comparing their efficacy with on another.

\section{Methods}

\section{Materials}

This experimental study was conducted in the Diagnostic Microbiology Lab of Imam Khomeini Hospital, Urmia, Iran in 2017. Mueller-Hinton agar (MHA), Mueller-Hinton broth (MHB), and skim milk containing $15 \%$ sterile glycerol (all purchased from Merck, Germany) were used for cultivation the bacteria, determining the MICs and MBCs, and storing the isolates. $B$. cepacia ATCC 10673 and E. faecalis ATCC 29212 were obtained from Iranian Biological Resource Center (IBRC) and Persian Type Culture Collection (PTCC) respectively and stored in skim milk containing $15 \%$ glycerol at $-20^{\circ} \mathrm{C}$. Three disinfectants including Deconex HLDPA (DH), Steranios 2\%, and Microzed Quatenol (MQ) were obtained from Armanbehboud, Ayriaborna, and Pharmedparto Company, respectively. These disinfectants are applied routinely as liquid chemical sterility agents in operation rooms and bronchoscopy and endoscopy units in our hospital. The basic compounds of each disinfectant are shown in Table 1.

\section{Preparation of serial dilutions of disinfectants}

Briefly, serial two-fold dilutions of disinfectants were prepared in sterile MHB. To prepare various concentrations of disinfectants, 27 sterile test tubes were numbered from 1 to 27 (As shown in Fig. 1). One mL of sterile MHB was added to each tube in aseptic conditions. One $\mathrm{mL}$ of testing disinfectant (undiluted) was poured into the tube No. 1; after mixing, serial two-fold dilutions were prepared by adding $1 \mathrm{~mL}$ of the contents of each tube to the next one. The process continued to the tube 25 (except for tubes 26 and 27). From tube 25, one milliliter was poured out, so the volume of all tubes was adjusted to $1 \mathrm{~mL}$. Tubes 26 and 27 were considered

Table 1 Basic compounds of tested antimicrobial agents

\begin{tabular}{llll}
\hline Brand of biocidal agents & $\mathrm{DH}$ & $2 \%$ Steranios & $\mathrm{MQ}$ \\
\hline $\begin{array}{l}\text { Basic compounds biocidal } \\
\text { agents }\end{array}$ & $\begin{array}{l}1200 \mathrm{PPM} \text { of Peracetic acid with Surfactant } \\
\text { Compounds }\end{array}$ & $\begin{array}{l}2 \% \mathrm{v} / \mathrm{v} \text { glutaraldehyde } \\
\text { solution }\end{array}$ & $\begin{array}{l}\text { Alcohol based with three types } \\
\text { of quaternary ammonium compounds }\end{array}$ \\
\hline
\end{tabular}




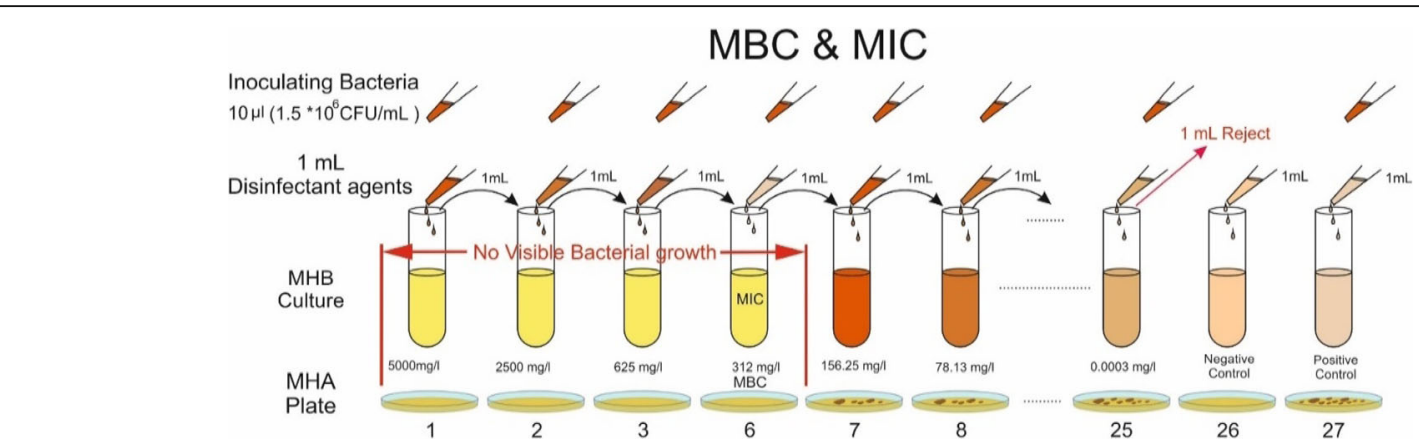

Fig. 1 Broth Dilution Method for determining MIC and MBC values of disinfectants against tested bacteria. MIC is equal to MBC $=312 \mathrm{mg} / \mathrm{L}$. The Mueller-Hinton broth (MHA) and Mueller-Hinton agar were used for determining MIC and MBC, respectively. The inoculum size was $1.5 \times 10^{6} \mathrm{CFU} / \mathrm{mL}$

as negative (disinfectant $+\mathrm{MHB})$ and positive $\left(1.5 \times 10^{6}\right.$ CFU of bacterial inoculums + MHB) controls, respectively. This procedure was done for all disinfectants. All experiments were done in triplicates for each tested disinfectant and each bacterial strain.

\section{Preparation of the McFarland turbidity standards}

McFarland turbidity standards were prepared as references for estimating the amount of bacterial inoculum. In this study, 0.5 McFarland turbidity standard was prepared [16] by adding $0.5 \mathrm{~mL}$ of $0.048 \mathrm{M}$ barium chloride $\left(1.17 \% \mathrm{w} / \mathrm{v} \mathrm{BaC}_{\mathrm{l} 2} \cdot 2 \mathrm{H}_{2} \mathrm{O}\right)$ solution to $99.5 \mathrm{~mL}$ of 0.18 $\mathrm{H}_{2} \mathrm{SO}_{4}(1 \% \mathrm{v} / \mathrm{v})$ and mixing with a magnetic stirrer. To compare the 0.5 McFarland turbidity standards with bacterial suspension, about $10 \mathrm{~mL}$ of this standard was transferred to a glass capped tube. The prepared solution should not be frozen and can be kept for up to 6 months. Vertex should always be applied before the use of turbidity standards and the standard cannot be used if rust or color change is observed or after the expiration date.

\section{Bacteria suspension}

The 0.5 McFarland standard [17] was used as a reference to compare the turbidity of bacterial inoculum in order to adjust the approximate cell density. Fresh cultures of bacterial strains were prepared on the MHA medium by overnight incubation at $37^{\circ} \mathrm{C}$. Then, 3-4 colonies of each bacterial strain were picked up with a sterile cotton swab and transferred to $4-5 \mathrm{ml}$ of sterile buffered saline. After mixing perfectly, turbidity was visually compared with the $0.5 \mathrm{McF}$ arland standard. After adjustment, the bacterial amount in the broth culture was approximately $1.5 \times 10^{8}$ colony-forming units per $\mathrm{mL}(\mathrm{CFU} / \mathrm{mL})$.

\section{Determination of MIC and MBC}

The susceptibility of the bacterial strains was determined using the modified microdilution method recommended by NCCLS (National Committee for
Clinical Laboratory Standards) guidelines [17]. $\mathrm{MIC}_{24}$ is defined as the lowest concentration of a biocide agent which has an inhibitory effect on the cultivated bacterium, causing no turbidity in the test tube after incubation at $37^{\circ} \mathrm{C}$ for $24 \mathrm{~h}$. After preparing serial dilutions, $10 \mu \mathrm{l}\left(1.5 \times 10^{6} \mathrm{CFU} / \mathrm{mL}\right)$ of 0.5 McFarland adjusted fresh bacterial culture was inoculated to each dilution and tubes were incubated at $37^{\circ} \mathrm{C}$ for $24 \mathrm{~h}$. Then, the test tubes were examined for their turbidity. The lowest concentration of a disinfectant that inhibited the bacterial visible growth was considered as MIC. To determine the minimum bactericidal concentration of disinfectants, $5 \mu \mathrm{l}$ of each tube was sub-cultured on the surface of MHA at $37^{\circ} \mathrm{C}$ for $24 \mathrm{~h}$ and then colony count was done. $\mathrm{MBC}_{24}$ was considered as the concentration of the disinfectant that prevented the growth of $99.9 \%(3-\log )$ of the bacteria as growing less than 15 colonies on MHA.

\section{Results}

The values of $\mathrm{MIC}_{24} \& \mathrm{MBC}_{24}$ for the tested disinfectants were as follows:

\section{Steranios $2 \%$}

In our hospital Steranios 2\% containing 2\% glutaraldehyde is commonly used as a disinfectant or sterilizer for critical and semi-critical items in an exposure time and concentration dependent manner. It is available in both forms of liquid or gas, but the liquid form is used in our hospital. The MIC and the MBC of Steranios 2\% for $E$. faecalis ATCC 29212 was $0.31 \mathrm{mg} / \mathrm{L}$. At sub-MIC doses with a lower concentration of the biocide, the tubes were turbid and the bacteria grew easily after cultivating on solid media. The MIC and the MBC of Steranios $2 \%$ for B. cepacia ATCC 10673 was $9.83 \mathrm{mg} / \mathrm{L}$ (Table 2).

\section{Deconex HLDPA (DH)}

DH is applied as a high-level disinfectant to sterilize reusable medical devices such as flexible endoscopes in 
Table $2 \mathrm{MIC}_{24}$ and $\mathrm{MBC}_{24}$ values of investigated disinfectants for B. cepacia ATCC 10673 and E. faecalis ATCC 29212

\begin{tabular}{|c|c|c|c|}
\hline \multicolumn{4}{|l|}{$\mathrm{MIC}_{\mathbf{2 4}}$ and $\mathrm{MBC}_{\mathbf{2 4}}(\mathrm{mg} / \mathrm{L})$} \\
\hline \multirow[t]{2}{*}{ Bacterial strains } & 2\%Steranios & $\mathrm{DH}$ & MQ \\
\hline & $\begin{array}{l}\mathrm{MIC}_{24}= \\
\mathrm{MBC}_{24}\end{array}$ & $\begin{array}{l}\mathrm{MIC}_{24}= \\
\mathrm{MBC}_{24}\end{array}$ & $\begin{array}{l}\mathrm{MlC}_{24}= \\
\mathrm{MBC}_{24}\end{array}$ \\
\hline $\begin{array}{l}\text { B. серасіа ATCC } \\
10673\end{array}$ & 9.83 & 78.13 & 70.31 \\
\hline E.faecalis ATCC 29212 & 0.31 & 9.77 & 2.2 \\
\hline
\end{tabular}

operating rooms and intensive care units. As shown in Table 2, The MIC and the MBC of $\mathrm{DH}$ for E. faecalis ATCC 29212 and B. cepacia ATCC 10673 was 9.77 mg/L and $78.13 \mathrm{mg} / \mathrm{L}$, respectively.
Microzed Quatenol (MQ)

MQ antimicrobial agents are ready-to-use disinfectants in hospitals, clinics, and dental settings that are applied in the form of spray on sensitive surfaces of electronic equipment, cameras, work tables and dental units in health-care centers. As shown in Table 1, in order to increase the efficacy, MQ contains alcohol and three types of quaternary ammonium compounds. The MIC and the MBC values of MQ for E. faecalis ATCC 29212 and B. cepacia ATCC 10673 were $2.2 \mathrm{mg} / \mathrm{L}$ and $70.31 \mathrm{mg} / \mathrm{L}$, respectively. The $\mathrm{MBC}$ values for both strains were equal to MIC values. According to Table 3, the concentration ranges for Steranios 2\%, DH, and MQ were 50350.0003, 5000-0.0003, and 4500.0-0.0003 mg/L,

Table 3 Concentration ranges and breakpoints of disinfectants used to determine the $\mathrm{MIC}_{24}$ and $\mathrm{MBC}_{24}$ values for B. cepacia ATCC 10673 and E. faecalis ATCC 29212

\begin{tabular}{|c|c|c|c|c|c|c|}
\hline \multirow{3}{*}{$\begin{array}{l}\text { Tube } \\
\text { NO }\end{array}$} & \multicolumn{3}{|c|}{$\mathrm{MIC}_{24}=\mathrm{MBC}_{24}(\mathrm{mg} / \mathrm{L})$} & \multicolumn{3}{|c|}{$\mathrm{MIC}_{\mathbf{2 4}}=\mathrm{MBC}_{\mathbf{2 4}}(\mathrm{mg} / \mathrm{L})$} \\
\hline & \multicolumn{3}{|c|}{ E. faecalis ATCC 29212} & \multicolumn{3}{|c|}{ B. cepacia ATCC 10673} \\
\hline & $2 \%$ Steranios & $\mathrm{DH}$ & MQ & $2 \%$ Steranios & $\mathrm{DH}$ & MQ \\
\hline 1 & 5035.00 & 5000.00 & 4500.00 & 5035.00 & 5000.00 & 4500.00 \\
\hline 2 & 2517.50 & 2500.00 & 2250.00 & 2517.50 & 2500.00 & 2250.00 \\
\hline 3 & 1258.75 & 1250.00 & 1125.00 & 1258.75 & 1250.00 & 1125.00 \\
\hline 4 & 629.38 & 625.00 & 562.50 & 629.38 & 625.00 & 562.50 \\
\hline 5 & 314.69 & 312.50 & 281.25 & 314.69 & 312.50 & 281.25 \\
\hline 6 & 157.34 & 156.25 & 140.63 & 157.34 & 156.25 & 140.63 \\
\hline 7 & 78.67 & 78.13 & 70.31 & 78.67 & $\mathrm{MIC}=\mathrm{MBC}=78.13$ & $\mathrm{MIC}=\mathrm{MBC}=70.31$ \\
\hline 8 & 39.34 & 39.06 & 35.16 & 39.34 & $39.06 \mathrm{TO}^{*}$ & $35.16 \mathrm{TO}^{*}$ \\
\hline 9 & 19.67 & 19.53 & 17.58 & 19.67 & 19.53 & 17.58 \\
\hline 10 & 9.83 & $\mathrm{MIC}=\mathrm{MBC}=9.77$ & 8.79 & $M I C=M B C=9.83$ & 9.77 & 8.79 \\
\hline 11 & 4.92 & $4.88 \mathrm{TO}^{*}$ & 4.39 & $4.92 \mathrm{TO}^{*}$ & 4.88 & 4.39 \\
\hline 12 & 2.46 & 2.44 & $\mathrm{MIC}=\mathrm{MBC}=2.20$ & 2.46 & 2.44 & 2.20 \\
\hline 13 & 1.23 & 1.22 & $1.10 \mathrm{TO}^{*}$ & 1.23 & 1.22 & 1.10 \\
\hline 14 & 0.61 & 0.61 & 0.55 & 0.61 & 0.61 & 0.55 \\
\hline 15 & $\mathrm{MIC}=\mathrm{MBC}=0.31$ & 0.31 & 0.27 & 0.31 & 0.31 & 0.27 \\
\hline 16 & $0.15 \mathrm{TO}^{*}$ & 0.15 & 0.14 & 0.15 & 0.15 & 0.14 \\
\hline 17 & 0.08 & 0.08 & 0.07 & 0.08 & 0.08 & 0.07 \\
\hline 18 & 0.04 & 0.04 & 0.03 & 0.04 & 0.04 & 0.03 \\
\hline 19 & 0.02 & 0.02 & 0.02 & 0.02 & 0.02 & 0.02 \\
\hline 20 & 0.0096 & 0.0095 & 0.0086 & 0.0096 & 0.0095 & 0.0086 \\
\hline 12 & 0.0048 & 0.0048 & 0.0043 & 0.0048 & 0.0048 & 0.0043 \\
\hline 22 & 0.0024 & 0.0024 & 0.0021 & 0.0024 & 0.0024 & 0.0021 \\
\hline 23 & 0.0012 & 0.0012 & 0.0011 & 0.0012 & 0.0012 & 0.0011 \\
\hline 24 & 0.0006 & 0.0006 & 0.0005 & 0.0006 & 0.0006 & 0.0005 \\
\hline 25 & 0.0003 & 0.0003 & 0.0003 & 0.0003 & 0.0003 & 0.0003 \\
\hline 26 & \multicolumn{6}{|c|}{ Negative controls (disinfectant $+\mathrm{MHB}$ ) } \\
\hline 27 & \multicolumn{6}{|c|}{ Positive (inoculum + MHB) } \\
\hline
\end{tabular}

*TO Turbidity was observed

${ }^{*}$ At this concentration and lower (Up to tube number 25 ) turbidity was observed and indicates a non-bactericidal range of disinfectants 

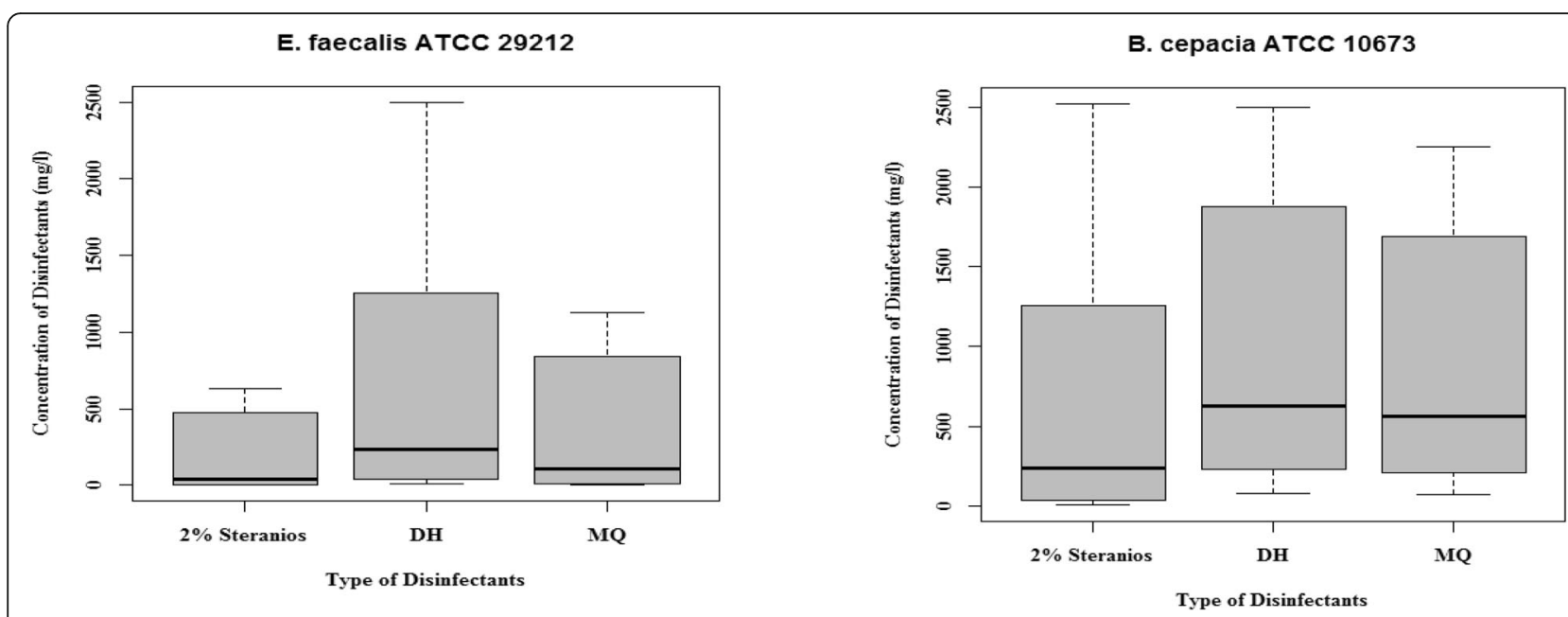

Fig. 2 Medians of tested disinfectants (Steranios 2\%, DH and MQ) concentrations as MIC = MBC (mg/L) on B. cepacia ATCC 10673 and E. faecalis ATCC 29212

respectively. Figure 2 presents the median values of data for disinfectants.

\section{Discussion}

Increased resistance of microorganisms to antibiotics and disinfectants and emergence of biocide-resistant bacterial strains have made it difficult to eliminate them. Disinfectants are effective in reducing health care associated infections, but the correct choice of disinfectants considering the wide range of efficacy against hospital pathogens is important and essential in this process [15, 18]. The purpose of this study was to evaluate the efficacy of three hospital disinfectants in two strains of pathogenic bacteria based on MIC and MBC tests. According to Tables 2, 3, and Fig. 2 the disinfectants did not have an equal efficacy in the tested strains and $B$. cepacia showed more resistance to all tested disinfectants compared to E.faecalis. It can be concluded that the same disinfectants should not be used for all wards, sections and places in healthcare settings. The results of this study showed that under the same conditions, different disinfectants revealed various efficacies and diverse ranges of activity against different bacterial strains. On the other hand, equal concentrations of disinfectants in the same application situation may have different effects on different types of bacteria. Therefore, before choosing and applying any disinfection in hospitals, it is absolutely necessary to measure the MIC and MBC values of daily used disinfectants against common lifethreatening bacterial agents or healthcare associated infections.

MIC and MBC assay tests are tools to determine the effectiveness of disinfectants against microorganisms and to determine the sensitivity of bacteria in health care settings $[19,20]$. If MIC and MBC values of a disinfectant are small enough, bacterial growth is inhibited at low concentrations of the disinfectant; in this case, the disinfectant is stronger, more effective, and suitable. In this situation, if the disinfectatnt is inexpensive (reasonable price), it is considered the best one compared to others. MIC values are usually less than MBCs, because higher concentrations of an antibacterial agent are needed for bactericidal versus bacteriostatic effects in most cases. MIC is the lowest concertation that inhibits the growth of tested bacteria, whereas $\mathrm{MBC}$ is usually a relatively higher concentration of the disinfectant that kills the microorganism. According to our findings, MIC and MBC of the two disinfectants were equal values in all experiments; this could be due to the optimal antibacterial properties of these biocidal agents. The MIC and $\mathrm{MBC}$ results of MQ showed that in the same conditions, it has different antibacterial effects on tested strains. $\mathrm{MQ}$, at a concentration of $\mathrm{MIC}=$ $\mathrm{MBC}=70.31 \mathrm{mg} / \mathrm{L}$, reduced the growth of $B$. cepacia ATCC 10673 to 3-Log (99.9\%), whereas a 3-Log reduction (99.9\%) in growth occurred at $\mathrm{MIC}=\mathrm{MBC}=$ $2.2 \mathrm{mg} / \mathrm{L}$ for $E$. faecalis ATCC 29212. Therefore, it can be concluded that either E. faecalis ATCC 29212 is more susceptible than B. cepacia ATCC 10673 to this disinfectant or the antibacterial effect of MQ is weaker on the B. cepacia ATCC 10673. Lower sensitivity of gram-negative versus gram-positive bacteria is mostly attributed to differences in chemical composition of gram-negative and gram positive cell walls, resulting in different bacteria behaviors against disinfectants. The cell wall of the gram-negative bacteria contains an outer membrane [21] that partly prevents the penetration of disinfectants and antibiotics into the bacterium. Acquisition of certain types of 
plasmids can make gram negative bacteria more resistant to biocides because of the production of detoxifying enzymes [22]. In this study, B. cepacia ATCC 10673 (gram negative) was more resistant to disinfectants compared to E. faecalis ATCC 29212 (gram-positive), but the mechanism of resistance was not investigated. Therfore, more detailed studies are required to explore the mechanism of resistance of the studied bacteria to these disinfectants.

E.faecalis showed a high sensitivity to Steranios 2\% $(\mathrm{MIC}=\mathrm{MBC}=0.31 \mathrm{mg} / \mathrm{L})$. However, in the same conditions, the lowest bacteriostatic and bactericidal concentration of Steranios $2 \%$ for B. cepacia was $9.83 \mathrm{mg} / \mathrm{L}$. It was also observed that E.faecalis was less resistant to lower concentrations of disinfectant. So, in hospital wards where E.faecalis is prevalent, even low concentrations of Steranios $2 \%$ can be applied for eradication of this strain. This recommendation should be taken with cautionbecause the rate of resistance to Steranios 2\% in other prevalent hospital-acquired pathogens should be determined and considered as well. The major components of Steranios 2\% are glutaraldehydes, which are used as high-level disinfectants in healthcare settings for sterilizing medical instruments such as endoscopes, lenses, rubber, plastic, etc. Glutaraldehyde has no corrosive properties and its shelf- life is 14 days [1]. It stimulates the skin, eyes, and respiratory tract and there are occasional health problems such as occupational asthma in dealing with glutaraldehyde [23]. Therefore, when glutaraldehyde is used as a disinfectant, care should be taken and attention should be paid to ventilation. The range of bactericidal (MIC) or bacteriostatic concentrations (MIC) of Steranios $2 \%$ was $5035-9.83 \mathrm{mg} / \mathrm{L}$ for $B$. cepacia and $5035-0.31 \mathrm{mg} / \mathrm{L}$ for E.faecalis. Pariscila et al. [11], showed that the MIC values of glutaraldehyde for E. cloacae, B. subtilis and E. coli were in the range of $2750-3750 \mathrm{mg} / \mathrm{L}$. Whereas, our results show that the MIC values were markedly lower in the present study (0.31 mg/L vs. $2750-3750 \mathrm{mg} / \mathrm{L}$ ).

Another disinfectant in this study was DH whose effectiveness was compared with other tested disinfectants. Its main ingredient is peracetic acid (PAA). Peracetic acid is a suitable alternative for decontamination of heat-sensitive medical equipment. This antibacterial agent has a rapid activity against bacterial spores, but it has corrosive effects on some metal equipment [24]. The present study also showed (Table 3 ) that $B$. cepacia was generally less sensitive to DH than E. faecalis. At 19.53 $\mathrm{mg} / \mathrm{L}, \mathrm{DH}$ showed marked antibacterial effects against $E$. faecalis whereas B. cepacia was more tolerant to it. The bactericidal concentration range of DH was 5000$156.25 \mathrm{mg} / \mathrm{L}$ for B. cepacia and $5000-19.53 \mathrm{mg} / \mathrm{L}$ for $E$. faecalis. So, it can be concluded that $19.53 \mathrm{mg} / \mathrm{L}$ of $\mathrm{DH}$ has bactericidal effects on $99.9 \%$ of $E$. faecalis population, but the same concentration is ineffective on B. cepacia. In another study, the MIC range of peracetic acid for B. cepacia and some gram-negative strains was 2310-4491 mg/L [19] which was in the scope of our study. The median concentration of Sterniose 2\% against E. faecalis and B. cepacia was lower than $\mathrm{DH}$ and $\mathrm{MQ}$, respectively (Fig. 2). In addition E. faecalis needs a lower bactericidal concentration range of disinfectants compared to B. cepacia and a lower median of a disinfectant is the most effective against pathogens.

MIC and MBC represent the minimum inhibitory and minimum bactericidal concentration of disinfectants at $24 \mathrm{~h}$ [25], However, to minimize the risk of infection in hospital environments, there is a need for a potent antibacterial activity in very shorter exposure time for disinfection of critical equipment. Therefore, future studies should be conducted to determine the bacteriostatic and bactericidal effects of disinfectants at short time exposures, including 5, 10, and $20 \mathrm{~min}$. Due to the limited number of critical items (e.g. endoscopic instruments, bronchoscopes, arthroscopy devices, etc.) in our hospital and the physicians' interest in visiting more patients in less time, it is recommended to determine the effective concentrations of various disinfectants (low, intermediate, and high level) in short contact times with pathogenic microorganisms. In this study, the bacteriostatic and bactericidal effects of three different disinfectants were investigated on reference isolates of $E$. faecalis and $B$. cepacia. It is obvious that bacterial isolates from patients, hospital personnel, or hospital environment are usually more resistant to antimicrobial agents, so further studies in a larger number of hospital isolates are recommended. The present study showed the different efficacy of three classes of disinfectants on two different strains of bacteria. Considering the variable effects of disinfectants on several nosocomial pathogens, alternate use of disinfectants in hospital wards is highly recommended. These findings could be used in hospitals or health care settings where the efficacy of disinfectants is important.

\section{Conclusion}

In conclusion the most effective surface and instrument disinfectants against both E. faecalis and B. cepacia were Steranios $2 \%(\mathrm{MIC}=0.31 \mathrm{mg} / \mathrm{L})>\mathrm{MQ} \quad(\mathrm{MIC}=2.20 \mathrm{mg} /$ $\mathrm{L})>\mathrm{DH} \quad(\mathrm{MIC}=9.77 \mathrm{mg} / \mathrm{L})$ and Steranios $2 \%(\mathrm{MIC}=$ $9.83 \mathrm{mg} / \mathrm{L})>\mathrm{MQ} \quad(\mathrm{MIC}=70.31 \mathrm{mg} / \mathrm{L})>\mathrm{DH} \quad(\mathrm{MIC}=$ $78.13 \mathrm{mg} / \mathrm{L}$ ), respectively. The use of non-lethal doses (sub-MIC) of disinfectants not only does not stop the growth of these pathogens but also increases the resistance level of microorganisms to disinfectants. The use of higher concentrations of disinfectants (above MBC) only 
results in overconsumption of disinfectants and is not cost-effective.

\section{Acknowledgments}

The authors would like to thank and appreciate the efforts and cooperation of the microbiology laboratory of Imam Khomeini Hospital, Urmia, Iran.

\section{Authors' contributions}

F.A; R.N provided the idea for this work and designed. F.H.G.M. data gathering. F.H; and F.D.M.Y;M.A.V.H Wrote the main manuscript text, discussed the scientific idea and reviewed the manuscript. All authors participated in writing the manuscript. All authors reviewed the manuscript All authors contributed to the scientific discussion. These authors jointly supervised this work. The author(s) read and approved the final manuscript.

\section{Funding}

The author (s) received no specific funding for this work.

\section{Availability of data and materials}

The datasets generated during and/or analyzed during the current study are not publicly available due to joint research and development with the company but are available from the corresponding author on reasonable request.

\section{Ethics approval and consent to participate}

Not applicable.

\section{Consent for publication}

Not applicable.

\section{Competing interests}

The authors of this article declare that they have no conflict of interests.

\section{Author details}

'Department of Environmental Health Engineering, School of Public Health, International Campus, Tehran University of Medical Sciences (IC-TUMS), Tehran, Iran. ${ }^{2}$ Department of Environmental Health Engineering, School of Public Health, Tehran University of Medical Sciences, Tehran, Iran. ${ }^{3}$ Center for Air Pollution Research (CAPR), Institute for Environmental Research (IER), Tehran University of Medical Sciences, Tehran, Iran. ${ }^{4}$ Department of Environmental Health Engineering, Faculty of Health, Kashan University of Medical Sciences, Kashan, Iran. ${ }^{5}$ Department of Microbiology, Faculty of Medicine, Urmia University of Medical Sciences, Urmia, Iran. ${ }^{6}$ Department of Environmental Health Engineering, School of Public Health, Iran University of Medical Sciences, Tehran, Iran. ${ }^{7}$ Clinical Research Development Unit of Emam Khomeini Hospital, Urima University of Medical Sciences, Urmia, Iran.

Received: 31 March 2020 Accepted: 9 July 2020

Published online: 22 July 2020

\section{References}

1. Rutala WA, Weber DJ. Guideline for disinfection and sterilization in healthcare facilities, 2008; 2008

2. Weinstein RA. Epidemiology and control of nosocomial infections in adult intensive care units. Am J Med. 1991;91(3):S179-84.

3. Peters A, Borzykowski T, Tartari E, Kilpatrick C, Mai SHC, Allegranzi B, Pittet D. "Clean care for all-it's in your hands": the may 5th, 2019 World Health Organization SAVE LIVES: clean your hands campaign. Antimicrob Resist Infect Control. 2019;8(1):64.

4. Dancer SJ. The role of environmental cleaning in the control of hospitalacquired infection. J Hosp Infect. 2009;73(4):378-85.

5. Boyce JM. Environmental contamination makes an important contribution to hospital infection. J Hosp Infect. 2007;65:50-4.

6. Obi C, Muhammad U, Manga S, Atata R, Hauwa T. Assessment of commonly used hospital disinfectants on bacteria isolated from the operating theatre. J Biosci Biotechnol Discov. 2016;1:59-65.

7. Block SS. Disinfection, sterilization, and preservation: Lippincott Williams \& Wilkins; 2001.

8. Sood S, Malhotra M, Das B, Kapil A. Enterococcal infections \& antimicrobial resistance. Indian J Med Res. 2008;128(2):111.
9. Brown AO, Singh KV, Cruz MR, Kaval KG, Francisco LE, Murray BE, Garsin DA. Cardiac Microlesions Form During Severe Bacteremic Enterococcus faecalis Infection. J Infect Dis. 2020. https://doi.org/10.1093/infdis/jiaa371.

10. Tiwari S, Rajak S, Mondal DP, Biswas D. Sodium hypochlorite is more effective than $70 \%$ ethanol against biofilms of clinical isolates of Staphylococcus aureus. Am J Infect Control. 2018;46(6):e37-42.

11. Mazzola PG, Jozala AF, Novaes LCL, Moriel P, Penna TCV. Minimal inhibitory concentration (MIC) determination of disinfectant and/or sterilizing agents. Braz J Pharm Sci. 2009;45(2):241-8.

12. Chun'ai Tao YG, Su W, Li Z, Tang X. Effectiveness of hospital disinfection and experience learnt from 11 years of surveillance. J Biomed Res. 2019;33(6):408.

13. Lotfipour F, Nahaei MR, Milani M, Javaherzadeh V, Omrani A, Attar N. Antibacterial activity of germicide-P: a Persulfate based detergent/ disinfectant on some hospital isolates. Iran J Pharm Sci. 2006;2(4):225-30.

14. Amini F, Yunesian M, Dehghani MH, Jazani NH, Nabizadeh Nodehi R, Moghaddam Arjomandi M. Comparison of Antiseptics' efficacy on pseudomonas Aeruginosa, StaphylococcusEpidermidis and Enterobacter Aeruginosa in Hospital of Imam Khomeini (Urmia). Iran J Health Environ. 2012:5(1):87-98.

15. Saint S, Kowalski CP, Kaufman SR, Hofer TP, Kauffman CA, Olmsted RN, Forman J, Banaszak-Holl J, Damschroder L, Krein SL. Preventing hospitalacquired urinary tract infection in the United States: a national study. Clin Infect Dis. 2008;46(2):243-50.

16. Andrews JM. Determination of minimum inhibitory concentrations. J Antimicrob Chemother. 2001;48(suppl_1):5-16.

17. Souza M, Lopes L, Bonez P, Gündel A, Martinez D, Sagrillo M, Giongo J, Vaucher R, Raffin R, Boligon A. Melaleuca alternifolia nanoparticles against Candida species biofilms. Microb Pathog. 2017;104:125-32.

18. Huslage K, Rutala WA, Sickbert-Bennett E, Weber DJ. A quantitative approach to defining "high-touch" surfaces in hospitals. Infect Control Hosp Epidemiol. 2010;31(8):850-3.

19. Penna TCV, Mazzola PG, Martins AMS. The efficacy of chemical agents in cleaning and disinfection programs. BMC Infect Dis. 2001;1 (1):16.

20. Rodrigues C, de Andrade F, de Vasconcelos L, Midena R, Pereira T, Kuga M, Duarte M, Bernardineli N. Antibacterial properties of silver nanoparticles as a root canal irrigant against Enterococcus faecalis biofilm and infected dentinal tubules. Int Endod J. 2018;51(8):901-11.

21. Anderson W, Huck P, Dixon D, Mayfield C. Endotoxin inactivation in water by using medium-pressure UV lamps. Appl Environ Microbiol. 2003;69(5): 3002-4.

22. Hancock RE. Resistance mechanisms in Pseudomonas aeruginosa and other nonfermentative gram-negative bacteria. Clin Infect Dis. 1998; 27(Supplement_1):S93-9.

23. Rideout K, Teschke K, Dimich-Ward H, Kennedy S. Considering risks to healthcare workers from glutaraldehyde alternatives in high-level disinfection. J Hosp Infect. 2005;59(1):4-11.

24. Sassi HP, Reynolds KA, Pepper IL, Gerba CP. Evaluation of hospital-grade disinfectants on viral deposition on surfaces after toilet flushing. Am J Infect Control. 2018:46(5):507-11.

25. Sayin Z, Ucan US, Sakmanoglu A. Antibacterial and antibiofilm effects of boron on different bacteria. Biol Trace Elem Res. 2016;173(1):241-6.

\section{Publisher's Note}

Springer Nature remains neutral with regard to jurisdictional claims in published maps and institutional affiliations.

Ready to submit your research? Choose BMC and benefit from:

- fast, convenient online submission

- thorough peer review by experienced researchers in your field

- rapid publication on acceptance

- support for research data, including large and complex data types

- gold Open Access which fosters wider collaboration and increased citations

- maximum visibility for your research: over $100 \mathrm{M}$ website views per year

At $\mathrm{BMC}$, research is always in progress.

Learn more biomedcentral.com/submission 